\author{
Asian Journal of \\ Medical and Biological Research \\ ISSN 2411-4472 (Print) 2412-5571 (Online) \\ www.ebupress.com/journal/ajmbr
}

\title{
Article \\ Scaling up of tigershrimp (Penaeus monodon) production in brackishwater pond under diversified cropping regimes
}

\author{
Mizanur Rahman Washim*, Syed Lutfor Rahman and AKM Shafiqul Alam Rubel \\ Bangladesh Fisheries Research Institute, Brackishwater Station, Paikgacha, Khulna-9280, Bangladesh \\ *Corresponding author: Mizanur Rahman Washim, Bangladesh Fisheries Research Institute, Brackishwater \\ Station, Paikgacha, Khulna-9280, Bangladesh. Phone +88-01723669600; E-mail:mizanbfri15@gmail.com
}

Received: 25 February 2018/Accepted: 18 March 2018/ Published: 29 March 2018

\begin{abstract}
To develop a scientific and affordable shrimp farming system for marginal to medium farmers with low inputs and higher returns by scaling up of production per unit area, shrimp culture was practiced with 3,5 and $7 / \mathrm{m}^{2}$ stocking densities for the period of 60 days as short cycle and 120 days as long cycle. All the hydrographical parameters were found congenial in different treatments except dissolved oxygen (DO) in case of higher stocking density and long culture pattern. However, the specific growth rate (SGR) was optimal in both culture cycle but increased sharply in first 3-4 weeks of grow out period. Distinct survival rate were found in different treatment which was ranged from 86.39 to $90.96 \%$ but did not show significant difference $(P>0.05 \%)$ among the treatments of short and long culture cycle. Total yield was ranged from $990 \mathrm{~kg} / \mathrm{ha}$ to 1998 $\mathrm{kg} / \mathrm{ha}$ for short cycled double and $1012 \mathrm{~kg} / \mathrm{ha}$ to $2032 \mathrm{~kg} / \mathrm{ha}$ for single cropping pattern. Highest production was obtained under the stocking densities of $7 / \mathrm{m}^{2}$ although the average production showed significant difference $(P<0.05 \%)$ among the treatments of both culture patterns. The food conversion ratio (FCR) value seems similar for all cropping patterns and ranged between 1.15 and 1.57 . Except stocking density of $7 / \mathrm{m}^{2}$ at short cycle culture, net benefit were significantly $(P>0.05 \%)$ higher in long cycle crop than that of aggregate of two short cycle crops. But benefit cost ratio (BCR) in short culture cycle is significantly $(P>0.05 \%)$ higher than that of long culture (120 days) which indicates higher net benefit as well as positive feasibility of short culture system. Considering the infrastructural facilities in farm level and resource capability, this shrimp farming technology would be appropriate to boost up the production and income particularly for marginal to medium farmers.
\end{abstract}

Keywords: diversified cropping; tiger shrimp; production; brackishwater; growth; production; cost; return

\section{Introduction}

Currently brackish water shrimp farming in Bangladesh is one of the most vainglorious sectors in terms of receiving an attention to earn huge amount substantial revenues and foreign currency to boost up national economy. The black tiger shrimp (Penaeus monodon) is the most widely cultured species in the brackishwater aquaculture of Bangladesh. The future of steadily expanding shrimp farming industry is largely dependent on the sustainable increment of unit area production. Bangladesh produced 2,23,582 MT shrimp/prawn in the year 2014-15 with an average production rate of $811 \mathrm{Kg} /$ hectare for all types of farming systems (DoF, 2016, National Fish Week-Bengali Compendium). But in the traditional or extensive method, on average $300 \mathrm{Kg} / \mathrm{ha}$ can be produced (The Daily Star, 2015) which is not sufficient enough that means we have to increase our per hectare production. The productivity of shrimp in other shrimp producing nations is much higher that is 4000 $\mathrm{kg} / \mathrm{ha}$ in Australia, $2500 \mathrm{~kg} / \mathrm{ha}$ in Thailand, $1500 \mathrm{~kg} / \mathrm{ha}$ in Malaysia and $670 \mathrm{~kg} / \mathrm{ha}$ in Philippines respectively as both of the country brought 60 percent of their farms under semi-intensive culture system (Rahman et al., 2013). Of the total shrimp farming area (2, 75,583 ha) of Bangladesh, only around 2,500-3,000 hectare area is being used under modern/scientific shrimp farming technology like semi-intensive method. From this figure we can surmise that a larger area of coastal impoundments can't be used effectively and remain underutilized in regard 
to rate of production. Similarly sudden disease outbreak is frequently disrupting our whole shrimp farming industry. Bangladesh Fisheries Research Institute (BFRI) have developed culture technology of shrimp with the provision of prevention of viral disease (Saha and Alam, 2008) which entails large amount of investment. However, most of the farmers still follow the traditional method due to having poor resources because modern and scientific culture technique is more cost effective and marginal to medium farmers are very reluctant to adopt scientific interventions of culture management for increasing production (Saha et al., 2016).

It is evident that we have enough scope to increase our total yield more by minimal intensification which is affordable by the marginal and medium farmers. Introduction of some technological interventions through diversified cropping system followed by modification in gher area, culture period, stocking density and other inputs would surely up rise production as well as profitability. Diversified cropping regime is a lower investment related culture system followed by modification in gher (pond) size, culture period, stocking density and other inputs that would surely up rise production as well as profitability. If traditional shrimp farmers can be technically efficient and impetuously accustomed with diversified cropping pattern ensuring lower management cost with higher production rate Bangladesh could successfully ensure a sustainable production in near future up to maximum level. Although, a great deal of research work have been conducted regarding stocking, growth, survival and production of (Washim et al., 2016; Hossain et al., 2013; Debnath et al., 2013; Latif and Alam, 2008; Gunarto et al., 2006; Saha et al., 2006 and Abu Hena et al., 2004), but no or limited publications have been addressed the diversified cropping system of shrimp farming. In this backdrop, the present study attempts to investigate the feasibility of the production behavior and profitability of the diversified shrimp farming operation focusing variation in culture period (short term-60 days \& long term-120 days) with different stocking densities in the southwest shrimp farming region of Bangladesh.

\section{Materials and Methods}

\subsection{Site of the experiment}

The experiment was carried out during May to August, 2016 at the Brackishwater Station of Bangladesh Fisheries Research Institute, Paikgacha, Khulna. Eighteen on-station earthen ponds having an average area of 0.1 ha each in the pond complex were selected for the study. The experiment covered a period of 120 days.

\subsection{Experimental design}

The experiment was designed with six treatments each with three replication viz. treatment $T_{1}$ and $T_{2}$ covered short (60 days) term and long (120 days) term culture period respectively with stocking density of $3 \mathrm{no} / \mathrm{m}^{2}$. Similarly treatment $\mathrm{T}_{3}$ and $\mathrm{T}_{4}$ covered the same culture period with stocking density of $5 \mathrm{no} / \mathrm{m}^{2}$ and treatment $\mathrm{T}_{5}$ and $\mathrm{T}_{6}$ also covered the same culture period with stocking density of $7 \mathrm{no} / \mathrm{m}^{2}$.

\subsection{Pond preparation and pre-stocking management}

Initially ponds were completely drained out and re-excavated to remove the fouled layer of pond bottom and allowed to sun dry for 7-10 days to increase the oxidation capacity of hydrogen sulphide and to eliminate other obnoxious gases.

For short term (10-15 days) nursing of shrimp post larvae in-pond nursery, about $10 \%$ area of each pond receiving the respective treatments was enclosed with nylon net fastened with bamboo frame. The entire ponds area was fenced by blue net as biosecurity to prevent entering virus carrier species. Soil liming was done with agricultural lime and dolomite (3:1 ratio) @ $250 \mathrm{~kg} / \mathrm{ha}$. The ponds were filled with tidal water up to a depth of $1.0 \mathrm{~m}$ by filtration with small mesh size filter net and then treated with chlorine @ 20 ppm to disinfect water and kill all animalcules. Organic fertilizers, such as fermented mixtures of molasses, rice bran and yeast were spread across the ponds at a ratio given in Table 2. After 2-3 days of molasses application mustard oil-cake were applied as liquid state@60 kg/ha. Then the ponds were fertilized with urea and TSP @ 25 and $30 \mathrm{~kg} / \mathrm{ha}$, respectively for quick development of colour of water and production of plankton. However, major inputs applied in this experiment are furnished at a glance in Table 1. 
Table 1. Major interventions followed in the experimental ponds.

\begin{tabular}{ll}
\hline Key features & Doses/application \\
\hline Liming of soil & $250 \mathrm{Kg} / \mathrm{ha}$ (Quick lime: dolomite $3: 1)$ \\
Chlorination & $@ 20 \mathrm{ppm}$ \\
Urea+TSP & $25+30(\mathrm{Kg} / \mathrm{ha})$ \\
Fermented Molasses mixture (Molasses: rice bran: yeast) & $140: 35: 0.60 \mathrm{~kg} / \mathrm{ha}$. \\
PL (Post Larvae) & PCR tested PL \\
In-pond nursing & 15 days \\
Dolomite (water) & @ $15 \mathrm{ppm}$ (Monthly basis) \\
Feed & CP feed \\
Pond depth & $1 \mathrm{Meter}($ Minimum $)$ \\
Zeolite & @ 4 ppm $\left(3^{\text {rd }} \& 4^{\text {th }}\right.$ month of culture $)$ \\
\hline
\end{tabular}

\subsection{Post stocking management}

After fertilization PCR tested post larvae $\left(\mathrm{PL}_{15}\right)$ were procured exclusively from commercial hatchery and acclimatized with the pond water and stocked slowlyas per mentioned design to the in-pond nursery during the late evening period. In the nursery the stocked PL were fed with CP nursery feed manufactured by India. After two week of nursery rearing, the juveniles were released to the whole pond by up-folding the nylon net of the nursery enclosure. In the grow-out ponds, the shrimp were fed with good quality commercial feed $e g$. CP feed depending on the biomass of shrimp. Growth of fishes was monitored at weekly interval and feeds were adjusted according to $\mathrm{CP}$ feed manual. The feeding frequency was 4 times per day as in the morning at 6.00 a.m., 11.00 a.m., 6.00 p.m. and 10.00 p.m. respectively. The ingredient of the feed includes Fish meal, Wheat flour, Soybean meal, Fish oil, Phospholipid, Vitamins and Minerals etc. The composition of CP feed applied in the culture ponds are given below in Table 2 .

Table 2. Composition of CP feed applied during the culture period.

\begin{tabular}{ll}
\hline Composition & Percentage \\
\hline Crude protein & 38 (Minimum) \\
Fat & 5 (Minimum) \\
Moisture & 12 (Maximum) \\
Fibre & 4 (Maximum) \\
\hline
\end{tabular}

Aeration was provided to the ponds whenever necessary through agitating water by paddle wheel/airjet but no aeration was applied in short culture ponds. As post stocking management, all ponds were limed @ 6-8 ppm with an equal mixture of $\mathrm{CaCO}_{3}$ and $\mathrm{CaMg}\left(\mathrm{CO}_{3}\right)_{2}$, fortnightly during the entire culture period. Additional liming (dolomite) was also done at the same rate after every heavy rainfall. Sampling was done in the pond every week during early hours of the day with cast net for checking the healthiness and growth rates.

\subsection{Monitoring of water quality}

During the grow out period the pond ecological variables viz., temperature, depth, transparency, salinity, $\mathrm{pH}$ and total alkalinity were monitored and determined at weekly interval following standard methods as mentioned by (APHA, 1992). Dissolved oxygen (DO) was monitored almost daily after 50 days of culture (DOC) in long culture system.

\subsection{Harvesting and data analysis}

After 60 days of culture, shrimps of all short cycle ponds (1st crop) were harvested by complete dewatering and the ponds were prepared again for $2^{\text {nd }}$ short cycle following all the previous interventions. After completion of grow-out period both in short and long culture pattern all the shrimp were harvested successfully by complete dewatering. Then growth, survival and production were estimated. ANOVA and DMRT was done to observe differences in growth, survival rate, yield, FCR values and economic returns within the treatments of short and long cycle culture pattern and the level of significance were considered at the 5\% $(P>0.05)$. Data was compiled and analyzed using software MS Excel and SPSS (Statistical Package for Social Science) version-20. The FCR (Food Conversion Ratio) and specific growth rate (SGR\%) was estimated following the formula given below. 
Amount of dry food $(\mathrm{g})$

$\mathrm{FCR}=\frac{}{\text { Live weight gain }(\mathrm{g})}$

$\ln$ Final weight $(\mathrm{g})-\ln$ Initial weight $(\mathrm{g})$

SGR $\%=\frac{\text { Number of culture days }}{\text { Nut }}$

3. Results and Discussion

3.1. Assessment of hydrographical parameters

The different physico-chemical parameters of the pond water under short and long culture patterns are presented in Table 3. All the hydrographical parameters varied minimally in different treatments except dissolved oxygen (DO) and salinity. Maintenance of good water quality is of great importance for optimum growth and survival of shrimps (Soundarapandian et al., 2010). The growth and survival of shrimps are affected by temperature, salinity and dissolved oxygen concentration suggested by (Subrahmanyam, 1973; Verghese et al., 1975 and Liao, 1977). However the water temperature values were varied between $29^{\circ} \mathrm{C}$ and $33^{\circ} \mathrm{C}$ in all the ponds and were slightly higher than the suitable range for growth of shrimp reported by (Boyd and Fast, 1992). Salinity is one of the most important ecological factors which affect the growth and survival of P. monodon (Chakroborti et al., 1986). In the present study salinity was found between 6.5-17 ppt during the culture period which complies with the report of (Predalumpaburt and Chaiyakam, 1994), where they recommended salinity ranging from 5.0-32.0 ppt is favourable for shrimp culture. The average $\mathrm{pH}$ was fluctuated within the range of 7.4 to 9.0 in different treatments which implies that the $\mathrm{pH}$ in all the pond water was more or less alkaline throughout the experimental period and the level is comparable with the observation of (Boyd and Green, 2002 and Islam et al., 2008).

DO should be considered as a key factor if success in shrimp culture is to be achieved and therefore DO levels of $>4.0 \mathrm{mg} / \mathrm{l}$ for shrimp culture has been recommended by (Zhang et al., 2006). Morning DO remained within the suitable limit and DO was recorded maximum $6.8 \mathrm{mg} / \mathrm{l}$ and the minimum was $3.3 \mathrm{mg} / \mathrm{l}$ in 5 and $3.1 \mathrm{mg} / \mathrm{l}$ in 7 stocking density of long culture in this case additional oxygen was supplied with aerators at late night hour usually after 91 days of culture whenever necessary. The transparency of the present study is between 25 and 45 $\mathrm{cm}$ which is similar to the agreement of (Ramakrishna, 2000; Soundarapandian and Gunalan, 2008). The recommended alkalinity is to be $>80 \mathrm{mg} / \mathrm{l}$ for successful culture of $P$. monodon (Hansell, 1993), however in the present experiment the alkalinity level in different treatments varied between 106 and $160 \mathrm{mg} / \mathrm{l}$ Table 3 that is conducive for shrimp culture.

Table 3. Water quality parameters in different treatments of short and long culture.

\begin{tabular}{|c|c|c|c|c|c|c|c|c|c|}
\hline \multirow[t]{2}{*}{ Variables } & \multicolumn{3}{|c|}{$\begin{array}{l}1^{\text {st }} \text { short cycle crop } \\
(60 \text { days) }\end{array}$} & \multicolumn{3}{|c|}{$\begin{array}{l}\mathbf{2}^{\text {nd }} \text { short cycle crop } \\
(60 \text { days }) \\
\text { ocking density }\left(\mathrm{Nos} / \mathbf{m}^{2}\right)\end{array}$} & \multicolumn{3}{|c|}{$\begin{array}{c}\begin{array}{c}\text { Long cycle crop } \\
(120 \text { days) }\end{array} \\
\left.\text { Stocking density (Nos } / \mathrm{m}^{2}\right)\end{array}$} \\
\hline & 3 & 5 & 7 & 3 & 5 & 7 & 3 & 5 & 7 \\
\hline $\begin{array}{l}\text { Tempe-rature } \\
\left({ }^{\circ} \mathrm{C}\right)\end{array}$ & $29.5-32.0$ & $30.5-31.5$ & $29.0-31.0$ & $30.0-31.5$ & $29.7-32$ & $30.5-32$ & $29.0-32.0$ & $30.5-31.5$ & $29.5-33$ \\
\hline Depth $(\mathrm{cm})$ & 106-124 & 然 & 25 & $2-2$ & 7 & 25 & 18 & 15 & 114-126 \\
\hline $\begin{array}{l}\text { Transpa- } \\
\text { rency }(\mathrm{cm})\end{array}$ & $27-38$ & $30-45$ & $28-40$ & $25-45$ & $28-44$ & $22-37$ & $32-47$ & $28-42$ & $25-36$ \\
\hline $\begin{array}{l}\text { Salinity } \\
(\mathrm{ppt})\end{array}$ & $11-17$ & $11-17$ & $11-17$ & $6.5-10$ & $6.5-10$ & $6.5-10$ & $7-17$ & $7-17$ & $7-17$ \\
\hline $\mathrm{pH}$ & $8.0-8.9$ & $7.5-8.4$ & 7.9-9.0 & 7.9-8.9 & $7.8-9.0$ & $7.4-8.4$ & $8.0-8.9$ & $7.5-8.5$ & $7.9-9.0$ \\
\hline $\begin{array}{l}\text { Morning } \\
\text { DO (mg/l) }\end{array}$ & $4.5-6.8$ & 3.4 & 3.3 & $3.5-6.5$ & 3.5 & .8 & $4.5-6.0$ & 3. & 6 \\
\hline $\begin{array}{l}\text { Alkalinity } \\
(\mathrm{mg} / \mathrm{l})\end{array}$ & $122-140$ & $134-158$ & $128-155$ & $115-135$ & $106-136$ & $128-160$ & $126-140$ & $134-160$ & $130-155$ \\
\hline
\end{tabular}

\subsection{Growth and production performance of shrimp}

For the convenience of comparative analysis and to draw out the result more cognizable, production of two short cultures has been assembled to fulfill the culture period of long culture (120 days). The specific growth rates (SGR) of shrimp in every week for all the ponds are depicted in Figures 1, 2 and 3. From the presented figure it 
can be surmise that in the first 3-4 week of grow-out period the SGR was higher in both short and long culture pattern and then reduce successively and evenly as long as the ending of culture period. The initial SGR was significantly higher in $2^{\text {nd }}$ short culture than $1^{\text {st }}$ short and long cycle culture. However, the highest deviation in SGR was observed in different treatments of $1^{\text {st }}$ short cycle culture. This variation is due to over fluctuation in moulting of shrimp in different treatment that may be the result of variation in water quality parameters and other ecological conditions of ponds.

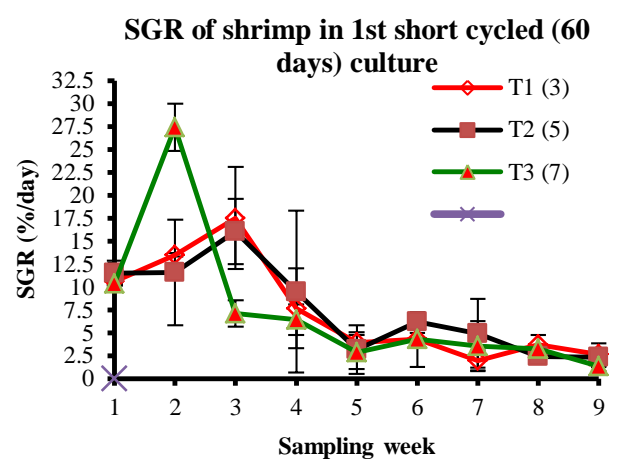

Figure1. SGR of shrimp in 1st short cycle.

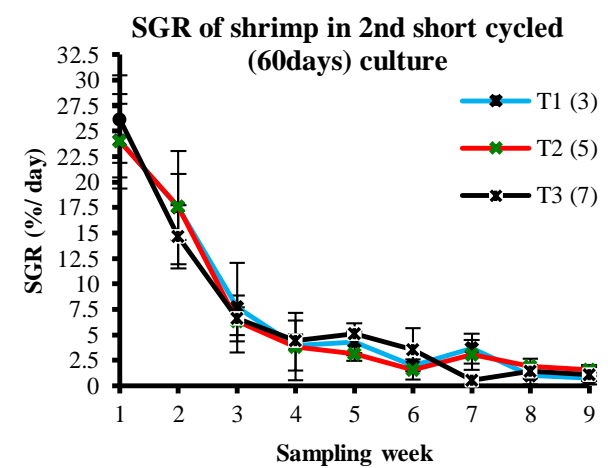

Figure 2. SGR of shrimp in 2nd short cycle.

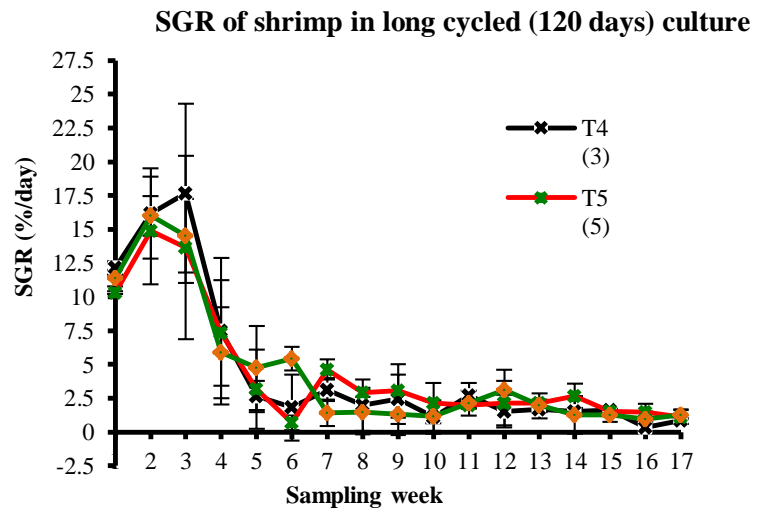

Figure 3. SGR of shrimp in long cycle (120 days) crop.

The production, survival rate and food conversion ratio (FCR) are shown in Table 4. Production of shrimp ranged between $990 \mathrm{~kg} / \mathrm{ha}$ to $1998 \mathrm{~kg} / \mathrm{ha}$ for short cycled double cropping pattern and1012 kg/ha to $2032 \mathrm{~kg} / \mathrm{ha}$ for single cropping system. The highest production was obtained from $\mathrm{T}_{6}$ of long culture $(2032.26 \pm 31.0 \mathrm{Kg} / \mathrm{ha})$ where the stocking density was $7 \mathrm{Nos} / \mathrm{m}^{2}$ whereas the lowest was $(990.17 \pm 2.52 \mathrm{Kg} / \mathrm{ha})$ in $\mathrm{T}_{1}$ of short culture where the stocking density was $3 \mathrm{Nos} / \mathrm{m}^{2}$ (Figure 4). But the production between $\mathrm{T}_{1}$ and $\mathrm{T}_{4} ; \mathrm{T}_{3}$ and $\mathrm{T}_{6}$ did not differ significantly $(P>0.05)$ although the average production showed significant difference $(P<0.05 \%)$ among the treatments of short and long culture patterns Table 4. However the production indices showed that the production was much more higher than the research report of (Islam and Alam, 2008), where production of shrimp culture for 120 days with stocking density $5 \mathrm{pcs} / \mathrm{m}^{2}, 7 \mathrm{pcs} / \mathrm{m}^{2}, 9 \mathrm{pcs} / \mathrm{m}^{2}$ were $759.14 \mathrm{~kg} / \mathrm{ha}, 670.77 \mathrm{~kg} / \mathrm{ha}$ and $701.24 \mathrm{~kg} / \mathrm{ha}$ respectively and the experiment of (Apud et al., 1984) where production of shrimp was only $340 \mathrm{~kg} / \mathrm{ha}$ with stocking density 4 to $5 \mathrm{pcs} / \mathrm{m}^{2}$ for 125 days with supplemental feed and improved water exchange system. Similarly the production rate at $5 \mathrm{Nos} / \mathrm{m}^{2}$ and $7 \mathrm{Nos} / \mathrm{m}^{2}$ density is closely similar to the production of $1380 \mathrm{~kg} / \mathrm{ha}$ in modified extensive system by (Laureatte et al., 2012) and (2431.3 $\pm 35.2 \mathrm{~kg} / \mathrm{ha})$ at 8 Nos $/ \mathrm{m}^{2}$ reported by (Hossain et al., 2013).

An outstanding survival rate were found in different treatment which was ranged from 86.39 to $90.96 \%$ but did not show significant difference $(P>0.05 \%)$ among the treatments of short and long culture cycle and the result is closely consistent with the survival rate reported by (Garriques and Arevalo, 1995 and Hossain et al., 2013), in probiotic treated ponds. Lowest FCR value was observed in $\mathrm{T}_{3}$ (short culture) and the value was $1.13 \pm 0.00$ and highest was found in $\mathrm{T}_{6}(1.57 \pm 0.01)$ of long culture with stocking density of $7 \mathrm{Nos} / \mathrm{m}^{2}$. However, there was 
significant $(P<0.05 \%)$ difference among the FCR value between different treatment of short and long culture as shown in Table 4. The FCR value of the present study is closely correspond with the FCR value reported for South East Asian countries shrimp farms (Corre, 1993) and survey result of (Ramaswamy et al., 2013) where they reported FCR value for different shrimp farming in India from 1.2 to 1.4. From the production and FCR data it can be clearly surmise that there was minimal significant difference among production of short and long culture with same stocking density although their FCR value differ significantly among different treatment.

The overall production and growth performance in both short and long culture cycle of crop diversification technology was satisfactory. These production rate implies that, production $(\mathrm{Kg} / \mathrm{ha})$ has been increased manifolds than the traditional culture practice. In the long cycle culture pattern it is obvious to supply additional oxygen for successful completion of grow-out period that is impossible to maintain by marginal and medium farmer. Similarly, for marginal and small farmer short culture (double crop) pattern will be more feasible because they could utilize their 1 st crop return in their second short cycle crop production as their investment capacity is limited.

Table 4. Production performance of Penaeus monodon in different treatments of short and long culture.

\begin{tabular}{|c|c|c|c|c|c|c|}
\hline \multirow{2}{*}{$\begin{array}{l}\text { Parameters } \\
\text { Treatments }\end{array}$} & \multicolumn{3}{|c|}{ Short culture $(60+60=120$ days $)$} & \multicolumn{3}{|c|}{ Long culture (120 days) } \\
\hline & $\mathrm{T}_{1}$ & $\mathrm{~T}_{2}$ & $\mathrm{~T}_{3}$ & $\mathrm{~T}_{4}$ & $\mathrm{~T}_{5}$ & $\mathrm{~T}_{6}$ \\
\hline $\begin{array}{l}\text { Stocking } \\
\text { density }\left(\mathrm{No} / \mathrm{m}^{2}\right)\end{array}$ & 3 & 5 & 7 & 3 & 5 & 7 \\
\hline Stocking size & $0.005 \pm 0.0$ & $0.005 \pm 0.0$ & $0.005 \pm 0.0$ & $0.005 \pm 0.0$ & $0.005 \pm 0.0$ & $0.005 \pm 0.0$ \\
\hline Production & $990.17 \pm 2.52^{\mathrm{a}}$ & $1485.23 \pm 7.15^{\mathrm{b}}$ & $1998.19 \pm 12.0^{\mathrm{d}}$ & $1012.31 \pm 4.34^{\mathrm{a}}$ & $1526.76 \pm 20.0^{\mathrm{c}}$ & $2032.26 \pm 31.0^{\mathrm{d}}$ \\
\hline Survival & $89.2 \pm 0.61^{\mathrm{a}}$ & $89.59 \pm 2.4^{\mathrm{a}}$ & $89.41 \pm 1.20^{\mathrm{a}}$ & $87.76 \pm 0.82^{\mathrm{a}}$ & $90.96 \pm 1.26^{\mathrm{a}}$ & $89.80 \pm 1.02^{\mathrm{a}}$ \\
\hline FCR & $1.16 \pm 0.01^{\mathrm{b}}$ & $1.17 \pm 0.01^{\mathrm{b}}$ & $1.13 \pm 0.00^{\mathrm{a}}$ & $1.51 \pm 0.01^{\mathrm{c}}$ & $1.52 \pm 0.01^{\mathrm{c}}$ & $1.57 \pm 0.01^{\mathrm{d}}$ \\
\hline
\end{tabular}

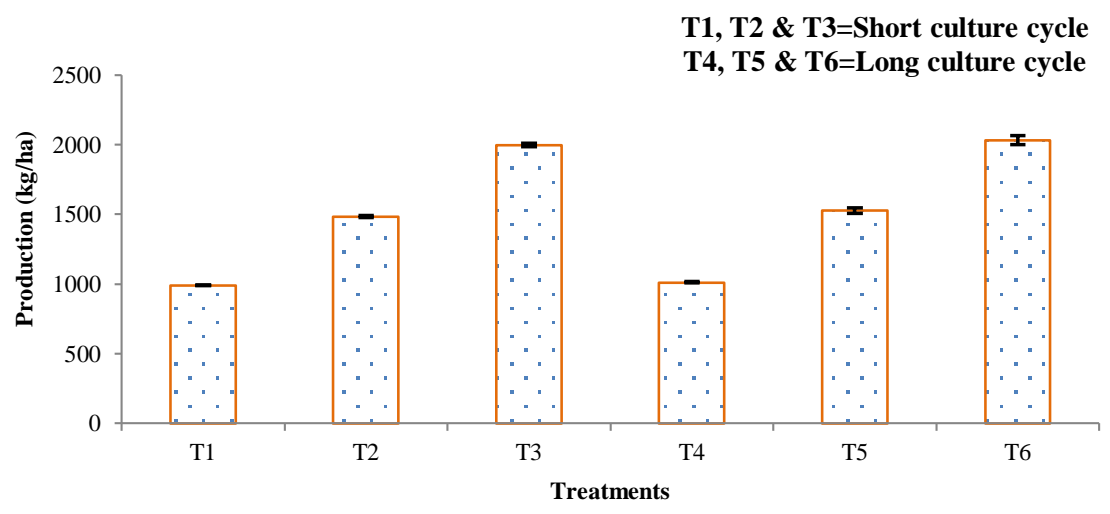

Figure 4. Production of shrimp in different treatments of short and long culture pattern.

\subsection{Economics and return status of shrimp}

The economic analysis of shrimp production under different stocking density covering short and long culture period has been presented in Table 5. Total amount of feed used were significantly $(P<0.05)$ varied among the treatments as the culture period was different among $\mathrm{T}_{1}, \mathrm{~T}_{2}, \mathrm{~T}_{3}$ as short culture (60 days) and $\mathrm{T}_{4}, \mathrm{~T}_{5}, \mathrm{~T}_{6}$ as long culture (120 days). The highest amount of feed was used in $\mathrm{T}_{6}(3190 \pm 7.0 \mathrm{~kg})$. The expenditure of feed was also significantly $(P<0.05)$ different among the treatments. The observed feed cost was highest in $\mathrm{T}_{6}(414700 \pm 910$ tk) and lowest was in $T_{1}(149257 \pm 1040 \mathrm{tk})$. For the successful completion of long culture (120 days) pattern supplementary oxygen were supplied with electric paddle wheels which appeared extra cost for all the treatments of long culture system.

On the other hand, the costs of PL were double for each treatment of short culture because of two times stocking. The highest total cost was observed in $\mathrm{T}_{6}(598627 \pm 910 \mathrm{tk})$ and lowest was observed in $\mathrm{T}_{1}$ (345557 \pm 1040 tk). However, the total cost was not significantly $(P>0.05)$ different between $\mathrm{T}_{1}$ and $\mathrm{T}_{4}$ but was significantly different compare to other treatments. Except $\mathrm{T}_{1}(543935 \pm 3308 \mathrm{tk})$ and $\mathrm{T}_{4}(556599 \pm 2389 \mathrm{tk})$ the selling price varied successively according to production variation with significant $(P<0.05)$ different among all the treatments. 
The calculated net benefit were significantly $(P<0.05)$ higher in $\mathrm{T}_{3}(526310 \pm 4521)$ and $\mathrm{T}_{6}(518862 \pm 15954)$ with a stocking density of $7 \mathrm{nos} / \mathrm{m}^{2}$ and there was also significant $(P<0.05)$ different between net benefit of different treatment of short and long culture cycle (Table 5). In West Bengal of India with scientific shrimp farming net benefit were BDT 1, 06,775/ha for small and BDT 4, 63, 458/ha for medium farmer reported by (Bhattacharya, 2009) which is closely similar with the present study. However, the net benefit (BDT 1, 98,378-2, 23,366/ha) obtained from short and long termshrimp culture with 3 stocking density in the present study is much higher than that of (BDT 56, 493.99-84,209.60/ha) reported by (Islam et al., 2008), at 3 stocking density and (BDT 50, 105/ha) at 2 stocking density (Shofiquzzoha et al., 2009), with same culture period.

Beside these, net benefitat $7 \mathrm{Nos} / \mathrm{m}^{2}$ is closely consistent with the research result of (Hossain et al., 2013) at stocking density $8 \mathrm{Nos} / \mathrm{m}^{2}$. The benefit cost ratio (BCR) in ponds with higher stocking density was higher in both culture pattern and there was no significant $(P>0.05)$ difference between BCR of different treatment of long culture cycle, otherwise it showed significantly $(P>0.05)$ lower than short term culture pattern.

Table 5. Cost of production and economic returns of shrimp from 1 ha ponds for short and long culture period.

\begin{tabular}{|c|c|c|c|c|c|c|}
\hline Parameters & Short culture ( & $60+60=120$ days $)$ & & Long culture (12 & 20 days) & \\
\hline Treatments & $\mathrm{T}_{1}$ & $\mathrm{~T}_{2}$ & $\mathrm{~T}_{3}$ & $\mathrm{~T}_{4}$ & $\mathrm{~T}_{5}$ & $\mathrm{~T}_{6}$ \\
\hline $\begin{array}{l}\text { Stocking } \\
\text { density }\left(\mathrm{No} / \mathrm{m}^{2}\right)\end{array}$ & 3 & 5 & 7 & 3 & 5 & 7 \\
\hline $\begin{array}{l}\text { Feed used } \\
(\mathrm{kg})\end{array}$ & $1148 \pm 8.0^{\mathrm{a}}$ & $1738 \pm 6.55^{\mathrm{b}}$ & $2278 \pm 4.04^{\mathrm{c}}$ & $1528 \pm 8.0^{\mathrm{d}}$ & $2320 \pm 9.01^{\mathrm{e}}$ & $3190 \pm 7.0^{\mathrm{f}}$ \\
\hline Feed cost $(\mathrm{tk})$ & $149257 \pm 1040^{\mathrm{a}}$ & $225971 \pm 847^{\mathrm{b}}$ & $296226 \pm 525^{\mathrm{c}}$ & $198640 \pm 1040^{\mathrm{d}}$ & $301686 \pm 1172^{\mathrm{e}}$ & $414700 \pm 910^{f}$ \\
\hline $\begin{array}{l}\text { Chemical } \\
\text { cost }(\mathrm{tk})\end{array}$ & $61300 \pm 0$ & $61300 \pm 0.0$ & $61300 \pm 0$ & $34927 \pm$ & 34927 & $34927 \pm 0.0$ \\
\hline PL cost $(\mathrm{tk})$ & $60000 \pm 0.0$ & $100000 \pm 0.0$ & $140000 \pm 0.0$ & $30000 \pm 0.0$ & $50000 \pm 0.0$ & $70000 \pm 0.0$ \\
\hline Labour cost (tk) & $75000 \pm 0.0$ & $75000 \pm 0.0$ & $75000 \pm 0.0$ & $75000 \pm 0.0$ & $75000 \pm 0.0$ & $75000 \pm 0.0$ \\
\hline $\begin{array}{l}\text { Electricity cost } \\
\text { (tk) }\end{array}$ & 0 & 0 & 0 & $4000 \pm 0.0$ & $4000 \pm 0.0$ & $4000 \pm 0.0$ \\
\hline Total cost $(\mathrm{tk})$ & $345557 \pm 1040^{\mathrm{a}}$ & $462271 \pm 847^{b}$ & $572526 \pm 525^{\mathrm{c}}$ & $333233 \pm 17897^{\mathrm{a}}$ & $465613 \pm 1172^{b}$ & $598627 \pm 910^{\mathrm{d}}$ \\
\hline Selling price(tk) & $543935 \pm 3308^{\mathrm{a}}$ & $821413 \pm 4350^{b}$ & $1098837 \pm 3998^{d}$ & $556599 \pm 2389^{a}$ & $839244 \pm 11018^{c}$ & $1117490 \pm 16864^{e}$ \\
\hline Net benefit(tk) & $198378 \pm 2284^{\mathrm{a}}$ & $359142 \pm 4003^{c}$ & $526310 \pm 4521^{\mathrm{d}}$ & $223366 \pm 18207^{b}$ & $373631 \pm 9852^{\mathrm{c}}$ & $518862 \pm 15954^{\mathrm{d}}$ \\
\hline $\mathrm{BCR}$ & $3.06 \pm 0.005^{\mathrm{b}}$ & $3.50 \pm .005^{\mathrm{c}}$ & $3.7 \pm .01^{\mathrm{c}}$ & $1.67 \pm .09^{\mathrm{a}}$ & $1.80 \pm .02^{\mathrm{a}}$ & $1.86 \pm .02^{\mathrm{a}}$ \\
\hline
\end{tabular}

However it is clear that BCR in short culture cycle is much higher than that of long culture (120 days) which indicates higher net benefit as well as positive feasibility of short culture system. Except stocking density of $7 / \mathrm{m}^{2}$ at short cycle culture net benefit were significantly $(P>0.05 \%)$ higher in long cycle crop than that of aggregate of two short cycle crops. Considering the infrastructural facilities (electricity) in farm level and resource capability (investment) of farmers, this culture technology would be appropriate to boost up the production and income particularly for marginal to medium farmers.

\section{Conclusions}

Finally it can be concluded that production rate $(\mathrm{kg} / \mathrm{ha})$ under diversified cropping system is significantly higher than the recorded national average production rate. If the extension department (DoF) could successfully disseminate this diversified shrimp culture technology in field level particularly among marginal to medium shrimp farmers, the total national shrimp production would successfully increase and the country's economy will be boost up by earning foreign currency from the sustainable and growing shrimp production.

\section{Acknowledgements}

The authors are profoundly grateful to the authority of Bangladesh Fisheries Research Institute (BFRI) for allowing enough funds for successful implementation of the research work.

\section{Conflict of interest}

None to declare. 
References

DoF (Department of Fisheries), 2016. National Fish Week, Compendium book (In Bengali) 2016. Ministry of Fisheries and Livestock, Department of Fisheries, Dhaka, Bangladesh, pp.126- 127.

The Daily Star, 2015. New shrimp farming system to boost yields. Access: 20/4/2017. http://www.thedailystar.net/new-shrimp farming system to boost yields-34026.

Rahman MC, MA Salam, NMF Rahman, MM Rahman and MM Hossain, 2013. Present Status and Potentiality of Shrimp in Bangladesh. Australian Journal of Basic and Applied Sciences, 7: 281-286.

Saha SB and MJ Alam, 2008. Improved technique of semi-intensive shrimp (Penaeus monodon) culture in closed system (in Bengali), Extension Booklet \# 32. Bangladesh Fisheries Research Institute, Brackishwater Station, Paikgacha, Khulna. 30 p.

Saha SB, S Nahar, A Ali and SL Rahman, 2016. Optimization of cropping pattern and stocking density for production of brackishwater shrimp, Penaeus monodon. Bangladesh J. Zool., 44: 31-40.

Washim MR, SL Rahman and S Nahar, 2016. Culture potential of SPF (specific pathogen-free) shrimp (Penaeus monodon) with special context of its growth and production performance in South-westcoastal region of Bangladesh. International Journal of Fisheries and Aquatic Studies, 4: 339-344.

Hossain MI, MM Kamal, MA Mannan, MAB Bhuyain and MI Hossain, 2013. Effects of probiotics on growth and survival of shrimp (Penaeus monodon) in coastal pond at Khulna, Bangladesh, J. Sci. Res., 5: 363-370.

Debnath PP, M Karim and QAZM Kudrat-E-Kabir, 2013. Comparative study on growth performance of bagda (P. monodon, Fabricius, 1798) in traditional and semi-intensive culture systems. Science and Technology, 3 : $1-16$.

Islam ML and MJ Alam, 2008. Optimization of stocking rates of tiger shrimp under modified improved culture system, J. Bangladesh Agril. Univ., 6: 341-348.

Gunarto, Muslimin and A Muharijadi, 2006. Tiger shrimp (Penaeus monodon) growth at diffrent stocking densities in high salinity pond using mangrove reservoir. Indonesian Aqua J., 1: 1-5.

Abu Hena MK, O Hishamuddin, K Misri and A Faridah, 2004. Culture of tiger shrimp Penaeus monodon fabricius using probiotics in brackishwater ponds in Perak, Malaysia, IIFET, Japan Proceedings.

APHA (American Public Health Association), 1992. Standard methods for the examination of water and wastewater. 18th ed., American Public Health Association, 1015 Eighteenth Street, N. W. Washington, D. C.

Soundarapandian P, V Ramanan and GK Dinakaran, 2010. Effect of probiotics on the growth and survival of Penaeus monodon (Fabricius). Current Res. J. Soc. Sci., 2: 51.

Subrahmanyam M, 1973. Experimental studies on growth in Penaeus monodon Fabricius, Proceeding Seminar on Mariculture and Mechanized Fishing, pp. 70-73.

Verghese PU, AN Ghosh and PB Das, 1975. On growth, survival and production of Jumbo tiger prawn, Penaeus monodon Fabricius in brackish water ponds, Bulletin Department of Marine Science University Cochin, 7 (4), pp. 781-789.

Liao IC, 1977. A culture study on grass prawn Penaeus monodon in Taiwan the pattern, the problems and the prospects. Journal of Fishery Society Taiwan, 5: 143-161.

Boyd CE and AW Fast, 1992. Pond monitoring and management. In: A. W. Fast and L. J. Lester (eds.), Marine Shrimp Culture: Principle and Practices, Elsevier Science Publications B.V.: 497-513.

Chakraborti RK, P Ravichandran, DD Halder, SKMandal and D Sanfui, 1986. Same physico-chemical characterstics of Kakdeeip Brackish Water ponds and their influence on the survival, growth and production of Penaeus monodon (Fab.). Indian J. Fish., 32: 224-235.

Predalumpaburt Y and K Chaiyakam, 1994. Impacts of shrimp farm effluent on water qualities. Technical Paper No. 7, NACA, 39 pp.

Boyd CE and BW Green, 2002. Coastal water quality monitoring in shrimp farming areas, an example from Honduras. Report prepared under the World Bank, NACA, WWF and FAO Consortium program on shrimp farming and the environment. Work in progress for public discussion.Published by the Consortium. $35 \mathrm{pp}$.

Zhang P, X Zang and G Huang, 2006. The effects of body weight, temperature, salinity, pH, light intensity and feeding condition on lethal DO levels of white leg shrimp, Litpenaeus vannamei (Boone, 1931). Aquaculture, 256: 579-587.

Ramakrishna R, 2000. Culture of the tiger shrimp Penaeus monodon (Fabricus) in low saline waters. M.Sc., dissertation, Annamalai University, pp. 1-31.

Soundarapandian P and B Gunalan, 2008. Recent technology for the survival and production of giant tiger shrimp Penaeus monodon along south east coast of India. Int. J. Zool. Res., 4: 21-27.

Hansell J, 1993. Health Management in Shrimp Ponds. Aquatic Animal Health Research Institute, Department of Fisheries, Kasetsart University Campus, Jatujak, Bangkok, Thailand. 2 pp. 
Apud FD, K Gonzales and N Deatras, 1984. Survival, growth and production of Penaeus monodon fabricius at different stocking densities in earthen ponds with flow-through systems and supplemental feeding. Fish. Res. J. Philippines., 6: 1-9.

Laureatte S, PP Suresh Babu, G Venugopa, RS Biradar, V Narashimacharyulu and P Mohan Das, 2012. Comparative evaluation of two farming practices of Penaeus monodon (Fabricius, 1798) in low saline waters of Andhra Pradesh, India. J. Mar. Biol. Ass. India, 54: 20-25.

Garriques D and G Arevalo, 1995. An evaluation of the production and use of a live bacterial isolate to manipulate the microbial flora in the commercial production of Penaeusvannzameipostlarvae in Ecuador, Eds. C. L. Browdy and J. S. Hopkins, Swimming through troubled water, proceedings of the special session on shrimp farming (World Aquaculture Society) pp. 53-59.

Corre V, 1993. The shrimp farming industry in Phillipines.Proceedings of the Aquaculture Workshop for SEAFDEC/AQD Training Alumni. SEAFDEC Aquaculture Department, Iloilo, Philippines.173 pp.

Ramaswamy UN, AB Mohan and M Metian, 2013. On-farm feed management: practices for black tiger shrimp (Penaeus monodon) in India. In M.R. Hasan and M.B. New, eds. On-farm feeding and feed management in aquaculture. FAO Fisheries and Aquaculture Technical Paper No 583. Rome, FAO. pp. 303-336.

Bhattacharya P, 2009. Economics of Shrimp Farming: A Comparative Study of Traditional Vs. Scientific Shrimp Farming in West Bengal. PhD Scholar, Institute for Social and Economic Change, Bangalore. p. 1112.

Islam MS, Y Mahmud and AMO Faruque, 2008. Effects of different types of feeds on growth and production of tiger shrimp, Penaeus monodon at Bagerhat region, Bangladesh. Bangladesh J. Fish. Res., 12: 205-212.

Shofiquzzoha AFM, MJAlam and M Moniruzzaman, 2009. Species diversification in coastal aquaculture: Production potentials of shrimp (Penaeus monodon) with mono and mixed sex tilapia. Bangladesh J. Fish. Res., 13: 179-184.

Hossain MI, AM Shahabuddin, MAB Bhuyain, MA Mannan, MND Khan and R Ahmed, 2013. Scaling up of stocking density of tiger shrimp (Penaeus monodon) under improved farming system in Khulna region of Bangladesh. American Journal of Experimental Agriculture, 3: 839-848. 